\title{
Partnering for bioregionalism in England: a case study of the Westcountry Rivers Trust
}

\author{
Hadrian Cook $^{1}$, David Benson ${ }^{2}$ and Laurence Couldrick ${ }^{3}$
}

\begin{abstract}
The adoption of bioregionalism by institutions that are instrumental in river basin management has significant potential to resolve complex water resource management problems. The Westcountry Rivers Trust (WRT) in England provides an example of how localized bioregional institutionalization of adaptive comanagement, consensus decision making, local participation, indigenous technical and social knowledge, and "win-win" outcomes can potentially lead to resilient partnership working. Our analysis of the WRT's effectiveness in confronting nonpoint source water pollution, previously impervious to centralized agency responses, provides scope for lesson-drawing on institutional design, public engagement, and effective operation, although some evident issues remain.
\end{abstract}

Key Words: adaptive comanagement; bioregionalism; bioregional planning; institutions; lesson-drawing; partnership

\section{INTRODUCTION}

Bioregionalism is a well-established philosophy that seeks to better connect communities with the governance of their local environment (McGinnis 1999). Such arguments relate back to earlier notions of eco-anarchism, which stress decentralized decision making and community control of environmental resources and economic activity (for example, Kropotkin 1974). Although definitions vary, several features of modern bioregionalism are evident relating to decision making powers, scale, participation, and knowledge use in governing environmental resources, in addition to environmental justice. For proponents, devolving powers to local communities, situated within ecologically distinct bioregions, can empower them to determine more effective environmental governance through utilizing local knowledge (Sale 1985, Aberley 1999, McGinnis 1999). Consequently, Pepper (1996:307) argues that the core "principles of bioregionalism" relate to,

... liberating the self, reducing the importance of impersonal market forces and bureaucracies, opening up local political and economic opportunities, enjoying communitarian values of cooperation, participation, reciprocity and confraternity, and having roots.

However, such normative arguments for greater local engagement in sustainable resource management raise empirical questions over its practical achievement and effectiveness vis-à-vis more traditional government agency approaches (for example, Benson et al. 2013). Indeed, Pepper (1996:308) himself identifies several potential implementation problems, including the evident need for higher level political coordination from "supra-regional and ... global bodies" to support localism and concerns that bioregions "have limited social or economic meaning in a modern world."

Potential models for bioregionalism are however discussed in the literature (see for example, Gray 2007). In addition, a nascent paradigm shift in environmental governing is alleged to be already occurring globally, away from top-down central agency management toward locally collaborative approaches (Margerum 2011, Benson et al. 2013, Cook et al. 2013). This shift is perhaps most visible in river basin management, which has increasingly witnessed regional or local rescaling of powers, partnership working, and local participation (Benson et al. 2013, see also Leach and Pelkey 2001, Sabatier et al. 2005, Smith and Porter 2009). Emerging comparative research also demonstrates the potential of geographically based institutional forms such as river basin organizations (RBOs) to support bioregional thinking at the regional or subregional catchment scale (Huitema and Meijerink 2014; D. Huitema and S. Meijerink, unpublished manuscript). Yet in the rush to meet such normative demands for greater bioregionalism, inappropriate institutional design could undermine RBO capacity to support this approach, necessitating further comparative case analysis for transnational "lessondrawing" (Benson and Jordan 2011).

In this respect, if bioregionalism is considered normatively desirable for governance, one potentially innovative example for learning comes from South West England (Cook et al. 2014). The Westcountry Rivers Trust (WRT) is an environmental charity established in 1995 to "secure the preservation, protection, development and improvement of the rivers, streams, watercourses and water impoundments in the Westcountry and to advance the education of the public in the management of water" (WRT 2012). Central to this approach is adaptive comanagement, which determines that "rights and responsibilities should be shared among those with a claim to the environment or a natural resource" (Plummer 2009). Such a modus operandi has potentially great currency for bioregionalism, for it could take river basin management away from a rather closed, technocratic practice to one where community values and local knowledge are centrally important. Indeed, the WRT's experience was cited by the UK Government as an exemplar of river basin management "good practice" (House of Lords 2012). Analyzing the Trust's institutional design and effectiveness could then provide lessons for bioregionalism, both nationally and internationally.

England and Wales are certainly not new to the "bioregional approach" in river basin management. As Cook (2016) shows, prior to the 1940s water governance was predicated on localized control with most management tasks, primarily water supply and sewage treatment, allocated to local municipal authorities and

${ }^{1}$ School of Natural and Built Environments, Kingston University, London, ${ }^{2}$ Environment and Sustainability Institute, Department of Politics, University of Exeter, Cornwall, ${ }^{3}$ Westcountry Rivers Trust, Stoke Climsland, Callington, Cornwall 
dedicated catchment scale agencies (internal drainage boards, fisheries boards, and catchment boards). Rationalization of this polycentric approach began with the Rivers Board Act 1948 that established a system of catchment based river boards to assume most functions (Bell and McGillivray 2000). River authorities then took control over these tasks, apart from sewage treatment and drinking supply, during the 1960s. In the early 1970s, tasks were then rescaled to 10 integrated regional water authorities (RWAs) with jurisdiction over broad river basins (Haigh 2005). After these bodies failed to tackle chronic water pollution, the Water Management Act 1989 created the National Rivers Authority, subsequently incorporated with Her Majesty's Inspectorate of Pollution into the Environment Agency (EA) in 1996, to enforce water pollution legislation (Cook 2016). Privatized water companies were also created by the Act to provide utilities. Thus, water governance became associated with agency management involving limited roles for the public and nonindustry actors. Introduction of the European Union (EU) Water Framework Directive (WFD) in 2000 obliged public participation in river basin management planning (Ker Rault and Jeffrey 2008). However, this process has been widely perceived as too top down in England, with the EA controlling it via limited participation within river basin liaison panels (Benson et al. 2014). Central government policy is, however, now promoting a subregional Catchment Based Approach to support river basin management planning (Defra 2013). Bioregionalization, under these policy initiatives, has occurred in parallel to rising activity at the local catchment level, with the widespread growth of partnership-type organizations that often have little or no connection to the WFD process (Cook et al. 2012).

Our analysis is based on multiple qualitative sources, derived from ongoing collaborative research conducted with the WRT. Primary and secondary data sources such as original documents, official reports, web sites, and personal correspondence were employed to support the analysis. Guiding this analysis was the collection of data on WRT institutional characteristics, actor strategies, and functional effectiveness measured in terms of legitimacy, accountability, coordination, and environmental performance. Documentary analysis was supported by interviews with key WRT staff, including its original founders and current senior management, along with agency officers and local actors. Interviewing focused on determining WRT evolution, actor roles, and functional effectiveness. Participant observation was also conducted, including attendance at Trust meetings and its operational activities, the aim being to develop a deeper understanding of how the organization functions in achieving its objectives.

\section{CONTEXT}

WRT's operations cover around $15,000 \mathrm{~km}^{2}$ of Devon, Cornwall, Somerset, and Dorset in South West England (Fig. 1). Although the Trust covers many rivers, including the Dart, Exe, Taw, and Teign, the River Tamar catchment $\left(1,800 \mathrm{~km}^{2}\right)$ was one of the first to be worked on and continues to be the test bed for new initiatives. Land use within the broader Tamar catchment is mixed, including arable and horticulture, with a predomination of grassland cover. Farm holdings are generally small, generating only modest financial returns. The area is bounded to the west by Bodmin Moor and to the east by Dartmoor, both characterized by upland acidic peat soils. Middle parts of the main catchment include areas of alluvial flats or wetlands, while coastal zones to the south contain littoral sediments. A major urban conurbation is the City of Plymouth, home to a population of $\sim 250,000$.

Fig. 1. The Westcountry Rivers Trust operational area (source: Ron Wundering; Huitema and Meijerink 2014).

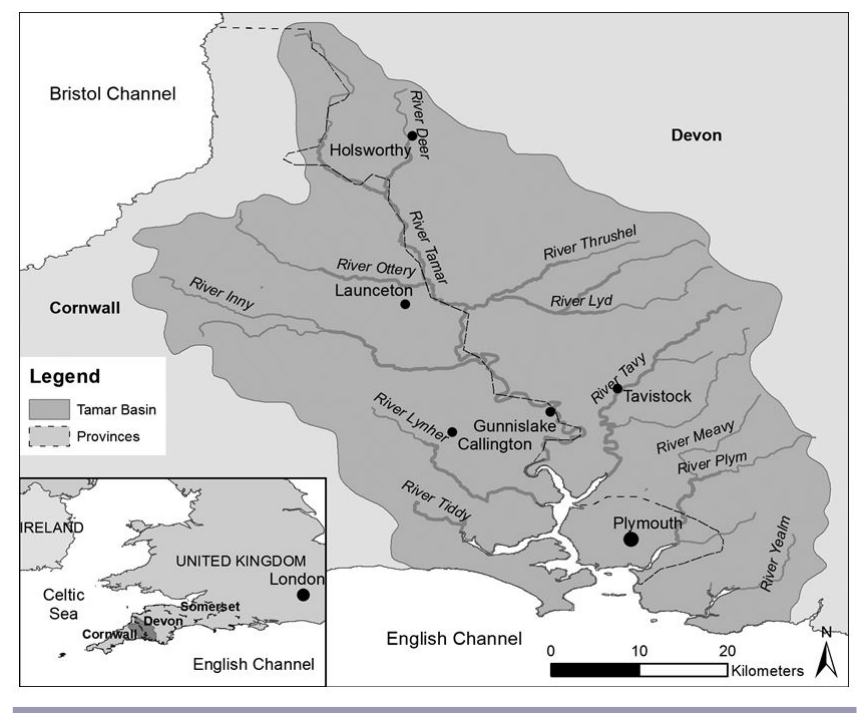

Multiple threats exist to these water resources, providing significant drivers for a consistent bioregional approach and adaptive comanagement. Diffuse agricultural and industrial pollution are the main barriers to effectively managing resources within the Trust's area. Intensive agriculture has resulted in threats to river and coastal water quality from nonpoint source pollution, mainly derived from widespread artificial and organic fertilizer application. High levels of animal stocking provide another critical source of diffuse water pollution. Further challenges to maintaining water quality emanate from the region's historical legacy of mining, particularly leaching from metals such as zinc and arsenic, and the production of china clay (Cornwall Rivers Project 2008). Wastewater treatment plants pose point source pollution risks, while the heavy modification of some rivers by industry is also influential.

Demands for water quality improvements come from three main drivers: legal-regulatory, economic, and cultural. At the European Union (EU) level, the WFD (European Communities 2000) legally compels the maintenance of "good" ecological and groundwater status for water bodies. Meeting the Directive requirements has involved the establishment of the South West River Basin District. Covering 21,000 km², the District comprises the counties of Cornwall, Devon, and Dorset and also encompasses areas of Somerset, Hampshire, Wiltshire, plus the Isles of Scilly. Environment Agency estimates in 2009 showed that $42 \%$ of surface water bodies met or exceeded good ecological criterion (EA 2009). However, even after subsequent EA investment in increased monitoring and tightening standards of assessment, the 2015 draft River Basin Management plan shows that only $23 \%$ of surface water bodies met or exceeded good ecological criterion (EA 2014). Critical economic factors driving demands for higher water quality standards are the tourism industry and drinking supply. Cornwall and Devon are highly 
dependent on visitors; in Cornwall nearly $15 \%$ of total employment occurs within this sector (ONS 2012). Tourists engage in multiple leisure activities that are dependent on high water quality, for example fishing, sailing, surfing, and visiting beaches. The Upper Tamar also provides an important source of drinking water for urban areas such as Plymouth. Finally, cultural demands have proved important to attempts to improve water quality, with local actors collaborating to find innovative ways to protect their natural environment. The Westcountry Rivers Trust owes its existence and continued development to concerned locals who reacted to declining water quality in their rivers to form a genuinely bottom up and community-led response.

\section{EVOLUTION}

The WRT originated in 1993 at a meeting between a group of friends and conservationists. They were concerned over the ecological condition of rivers in the Tamar area, which was still declining despite repeated regulatory interventions by government agencies. Following initial discussions, the participants decided to create a charitable trust to address these problems. A local resident, Arlin Rickard, was appointed as the Trust's first director. From the start, the WRT's aims were defined as improving the quality of local rivers while helping to increase biodiversity and protect natural habitats. These aims were supported by several core principles, namely that catchment management should benefit the community and be supported by partnership working and sound scientific evidence. This latter commitment was initially supported by an agreement with the Royal Holloway Institute for Environmental Research.

The trustees then applied for charitable status which, once granted, allowed them to seek funding, primarily from the European Union and the UK government. Three major projects were initially funded from these sources. First, a pilot project, the Tamar 2000 SUPPORT (1996-2000), was undertaken by the Trust with the aim of reducing diffuse water pollution in its catchment. Project work was supported by EU regional structural funding (Objective 5b), UK government finance provided by the Ministry of Agriculture, Fisheries and Food (MAFF), and from multiple private donations. The project successfully supplied around 300 land managers with targeted advice regarding how to maximize economic benefits with effective environmental stewardship. This advice was included within individually tailored plans that provided programs of best management practices for every farm. Programmatic techniques recommended included reducing fertilizer use, fencing erosion-prone river banks to prevent livestock damage, establishing riparian buffer zones to enhance soil conservation, and improving ditch management. A collaborative management approach was adopted, with strategic partners including the National Rivers Authority (subsequently replaced by the Environment Agency), the consultants DBD Associates who supplied technical advice to individual farmers, and the Wetlands Ecosystem Research Group.

After its early successes, the Trust secured funding for two successive developmental stages. After receiving new funding from the EU and MAFF, again under Objective 5b structural funds, it initially created the Westcountry Rivers Project in 2000 (Phase I). Designed to extend integrated catchment management approaches beyond the Tamar to the rivers Torridge and Taw, the Project also employed a targeted approach to provide another 300 farmers and water managers with individual best management practice advice and also guidance on rehabilitating landscapes. Phase II started in 2002. Known as the Cornwall Rivers Project, it was supported by an Objective 1 structural fund grant of $£ 744,500$, a figure match-funded by Defra (the Department of the Environment, Food and Rural Affairs, which succeeded MAFF). Further funds, in total $£ 1.86$ million, were secured from the private sector to supplement these grants. Phase II expanded the initial program into Cornwall, with several catchments targeted between 2002 and 2004; namely the rivers Camel, Cober, East and West Looe, Fal, Fowey, Inny, Lynher, Neet, Ottery, Seaton, and Strat. Additional funding helped extend the program into 2005. Several other rivers, including the Caerhays, Gannel, Menalhyl, Mevagissey, and White, were then included, bringing the total area covered to $2,455 \mathrm{~km}^{2}$, of which a high percentage was agricultural land (Defra 2006). By this point, the Trust calculates that around 870 riparian owners and farmers had been offered individually tailored assessments, along with an integrated management plan and advice. The latter approach was supported by the production of Best Practice information sheets. A system of "champion farmers" demonstration sites were also used to highlight effective management techniques and promote learning. The results generally proved positive, with Defra (2006:9) noting that the advice had generated " $£ 1369$ per farm in efficiency savings, soil retention, [and] improved nutrient management." According to the Trust, in addition to the advice disseminated, multiple river basin resource management plans were established along with the surveying of over $260 \mathrm{~km}$ of river, the completion of management actions such as 75 buffer zones, and the fencing of in excess of $100 \mathrm{~km}$ of riverbank to stop livestock erosion.

Thereafter, the Trust expanded operations with several additional projects. Funding from the EU INTERREG scheme was utilized in the Atlantic Aquatic Resource Conservation (AARC) project, the Wetted land: The Assessment, Techniques \& Economics of Preservation (WATER) project, and COLLABOR8, a project designed to foster regional sustainable development in northwest Europe. These initiatives have been undertaken in parallel to the River Improvement Project in Cornwall and Devon. Using funding from the Catchment Restoration Fund, the Project focuses on enhancing the ecological health of the rivers Axe, Dart, Exe, Teign, and others. The WRT is also collaborating with the River Exe and Tributaries Association to improve salmon habitats in the Exe catchment.

As a consequence, the WRT has steadily grown both institutionally and geographically. Activities of the Trust when it registered as a charity were initially restricted to the Torridge and Taw catchments. However, the Charity Commission, a UK government department that regulates charities, considered this approach as too limited resulting in operations being extended across Devon and Cornwall. During the project development phases, the Trust then expanded into Dorset and Somerset. More recently, the creation of The Rivers Trust (formerly the Association of Rivers Trust), the Bristol Avon Rivers Trust, and the Wessex Chalk Stream Trust, has seen the boundaries of the WRT defined by its relationship to these neighboring organizations.

\section{Current characteristics}

Current WRT approaches to water management revolve around bioregional planning. One major problem with any current analysis of sectoral interests is that it could seriously distort the 
role of food production in the rural economy. Planning is consequently employed by the WRT to produce a series of "aspirational maps" for differing land uses and management scenarios, for example in prioritizing water quality (for human consumption and conserving habitats), recreation, carbon sequestration, or habitat conservation specifically. Use is made of Weighted Geographic Information System (GIS) overlays to integrate environmental data into map production as a basis for "intelligent catchment design" (WRT [date unknown]). This process involves the creation of GIS layers for the following: clean and fresh water ecology; clean and fresh drinking water; water regulation for flooding; water regulation for drought; a climate layer (greenhouse gas regulation and air quality); recreation and tourism; and habitat provision. The layers are then synthesized into an Environmental Services model that allows spatial comparison with data on the intensity of agricultural production to determine conflicts. From the model, it was calculated that $6 \%$ of agricultural land conflicted with conservation priorities, allowing the Trust to better target and support landowners in these potential hotspots (WRT [date unknown]).

Another key management approach, which integrates with bioregional planning, is using market-based instruments. The UK agricultural industry is undergoing an historic shift, from providing for national food security to (in part) providing for environmental goods and services, over the last 30 years (Cook 2016). Support for agriculture from the EU and national government partially switched from mechanisms such as price support to agri-environmental schemes, although the latter still remain limited in comparison. Recently there has been a move internationally toward Payments for Ecosystem Services (PES) whereby a beneficiary pays for ecosystem improvements. Sources of funding may be either public or from a private concern (Dunn 2011, URS/Scott Wilson 2011), such as a water company that stands to benefit from environmentally sensitive land management practices. Although demands to provide cheap, secure food production are less frequently acknowledged today, the water industry increasingly looks to farmers as environmental service providers (M. Ross, personal communication, 2010).

Payments for Ecosystems Services is an important feature of the WRT integrated management approach, as illustrated by other current initiatives. First, the Trust is collaborating with the private water supplier South West Water in The Upstream Thinking project (South West Water [date unknown]). Through this PES scheme, the WRT have invested over $£ 2.2 \mathrm{~m}$ of grant within $£ 4.3$ $\mathrm{m}$ of overall expenditure, leading to 184 farm projects (ranging from slurry pits, yard roofing, and manure stores) as well as over $50 \mathrm{~km}$ of river bank fencing. Included within this project was the first UK reverse auction for water quality intervention measures (Day and Couldrick 2013). The innovative nature of the project demonstrates how a voluntary sector body can act as an ethical or honest broker in bringing together a willingness to pay for an environmental good, in this case by the water company, with a provider of these goods, namely farmers. Second, the WRT has helped develop the Westcountry Angling Passport Scheme, which operates by providing financial incentives to farmers and riparian owners to protect river water quality through the generation of revenue from anglers. Through these initiatives, the Trust performs an important function in identifying win-win gains for all stakeholders. Here, the creation of new markets can contribute to farm profitability and commercial diversification while protecting the environment. Given the success of these schemes, the WRT is now developing further PES-type instruments including the following: reverse auctions for flood storage and roof water diversion from combined sewerage overflows; country sports recreation (via the Country Sports Project, partly funded by the Rural Development Programme for England); carbon sequestration; and collaborating with supermarkets to promote sustainable food production.

Finally, the WRT has hosted other projects, including the Tamar Catchment Partnership (TCP). Comprising over 100 stakeholders drawn from 30 different organizations, the TCP aimed at reducing communication failures with stakeholders in catchment management. The methodology chosen involved the creation of stakeholder working groups, each responsible for different management aspects: carbon sequestration; water quality and quantity (floods and droughts); and habitats, both for wildlife and culture/recreation. Each group consisted of experts, service providers such as farmers and landowners, and service customers, for example, businesses. Use was made of GIS mapping to identify multifunctional areas potentially suitable for PES. Partners consequently were better placed to appreciate the values of catchment resources and identify actions for cost/benefit improvements (L. Couldrick 2013, unpublished manuscript).

\section{INSTITUTIONAL DESIGN, POLITICAL STRATEGIES, AND FUNCTIONAL PERFORMANCE}

\section{River basin organization institutional design: from agency to partnership working}

River basin organizations can be understood through a typology of institutional arrangements, based on several rules: authority; aggregation; boundary; information; and pay-off (Ostrom 1986). These can be used to categorize river basin organizations, including agency and partnership forms (Huitema and Meijerink 2014).

The requirements of EU water policy, in the form of the Water Framework Directive (WFD), means that the institutional characteristics of river basin management at regional scales in England and Wales conform to an agency type mode ${ }^{[1]}$. In terms of WFD implementation, authority rules (Ostrom 1986), i.e., actions assigned to a specific position, have been centrally imposed by the Environment Agency, the government designated competent authority (Table 1). Ten regional scale river basin districts have been established to undertake river basin management planning within the context of Directive requirements to achieve good ecological status objectives for waters. Aggregation rules (Ostrom 1986), specifying decisionmaking functions, have involved the Environment Agency delegating some planning activities to nonstate actors at the river basin scale, although coordination mechanisms are limited. River basin liaison panels, comprising the EA, government agencies, business representatives, regional authorities, and local government, provide advisory direction to planning (Benson et al. 2014). Yet, their influence has been questioned as panel members are centrally appointed by the EA, which also chairs planning meetings and coordinates responses (Fritsch and Benson 2013). If boundary rules (Ostrom 1986), which specify how participants are chosen, are considered, these RBOs also 
conform to an agency-type approach. Their geographical boundaries were centrally determined by the UK government and the EU Commission. A technocratic management approach, based on applying engineering and scientific expertise, has been adopted by the Environment Agency. Meanwhile, public participation in planning is constrained by obligations in the WFD. Information rules (Ostrom 1986), determining communication between participants, also reflect characteristics of an agency type RBO. Information provision on planning is mainly provided via Agency reporting to government and the EU, although such data is made publicly available. Finally, centralized pay-off rules (Ostrom 1986), prescribing the costs and benefits to participants, are primarily aimed at supporting the Environment Agency in meeting water quality objectives within the confines of departmental budgets, still constrained by government fiscal austerity. Although this approach remains the dominant water management paradigm, recent years have witnessed the emergence of novel river basin organizations that together map out an increasingly polycentric governance landscape at the subregional scale.

Table 1. The different institutional features evident in the agency type River Basin Districts and partnership Westcountry Rivers Trust.

\begin{tabular}{lll}
\hline \hline Rule types & River Basin Districts & Westcountry Rivers Trust \\
\hline Authority & Centralized decision & $\begin{array}{l}\text { Collaborative decision } \\
\text { making }\end{array}$ \\
Aggregation & $\begin{array}{l}\text { Delegated central } \\
\text { control, weak } \\
\text { coordination }\end{array}$ & $\begin{array}{l}\text { Consensus and strong } \\
\text { coordination between }\end{array}$ \\
& Centrally determined & actors \\
poluntary and locally \\
Boundary & Centralized reporting, & Local knowledge and \\
& technocratic knowledge & scientific evidence \\
Information & generation & \\
& Centralized objective & Costs and benefits shared \\
& achievement & between actors (win-win \\
Pay-off & & solutions) \\
& &
\end{tabular}

These institutional innovations can be categorized as partnership forms of RBO, as defined by Huitema and Meijerink (2014). Cook et al. (2012), in their survey of English and Welsh catchment partnerships, identify several distinctive features within this institutional shift. In contrast to the agency-type RBOs, partnerships were based on collaborative authority rules. Group memberships reflected multiple sectors, with private individuals accounting for $18 \%$ of group membership and only $22 \%$ of participants drawn from public institutions including government agencies (Cook et al. 2012). Rather than being established by centralized agency compulsion, partnerships had become initiated in response to diverse "wicked" problems, for example declining river water quality or local habitat loss. Because many groups based decision making on negotiation and consensus, aggregation rules meant that institutions were generating high levels of participant trust and reciprocity. Boundary rules were generally not centrally imposed among these partnerships, reflected in the mainly voluntary and localized nature of membership. In this respect, the majority $(46 \%)$ of partnerships were constituted as charities or limited companies (36\%), with a prevalence of local stakeholder ownership (Cook et al. 2012).
Information rules and pay-off rules also emphasized localized and scientific knowledge in decision making, while sharing out the costs and benefits of collaboration through seeking win-win outcomes for all actors. For example, some groups supported local farmers in reducing nutrient run-off through providing help with implementing best management practices. As a result, farmers could then increase their operational profitability through reducing fertilizer inputs, with attendant benefits for improved water quality and ecology.

Within this shift toward bioregionalism, the WRT is an exemplar of this novel type of partnership RBO in terms of its institutional architecture. First, its authority rules have evolved to frame a collaborative, nonhierarchical, and institutionally self-organizing organization that is independent of central state agencies. As discussed above, these institutions focus on integrated catchment management premised on sustainable development of the local economy and maintaining ecological resources. Second, the Trust's aggregation rules have been developed to promote consensual decision making with multiple stakeholders, including farmers and industry. Here, the WRT may be considered representative of its local constituency, particularly among the small-scale farming enterprises that are prevalent in the area. Third, boundary rules are used to determine partnership membership, which includes full time and voluntary staff. Currently, 30 staff are employed. They collectively possess expertise in several areas:

- Freshwater, marine, estuarine, and terrestrial ecology and conservation;

- Spatial data, mapping and modeling using GIS;

- Catchment modelling and risk assessment;

- Agricultural, land, and environmental management.

To manage the operations of the Trust, this expertise is divided into teams for overall management, fisheries management, land management, finance and data, evidence, and communication. Various volunteers and scientific experts help support their project implementation work. Boundary rules are also determined by charitable status, with UK law specifying that such voluntary organizations must provide benefits to the public. Charities must also be governed by a board of trustees who are legally responsible for decision making, including all expenditure (Cook and Inman 2012). Charities can employ staff but they mainly rely on dedicated volunteers who donate their time. Fourth, information rules emphasize both the inclusion of local knowledge but also a requirement for sound science as integral to the integrated catchment management approach adopted. Information from farmers, businesses, and the general public is consequently elicited in project design and implementation, in addition to evidence from epistemic actors. Finally, pay-off rules ensure that the interests of local communities are prioritized.

One example of how these pay-offs are supported is the PES strategy. To summarize from D. Bright (personal communication, 2010, 2012) and interviews with Trust managers, the WRT approach is based on five core principles that have been specifically adapted for agriculturally dominated rural areas:

- Bioregional planning: taking a holistic approach to catchment management, including economic dimensions and statutory regulation; 
- Community conservation: nothing can progress without local leadership and support; achieving win-win situations is central to the philosophy;

- Payment is via the market: a major source of funding for ecosystem services comes not through public expenditure (that is from European, UK, or local revenues) but from the direct beneficiaries of environmental gain;

- Working sequentially to engage the public;

- An honest broker is sought who mediates the flow of cash from beneficiary to service provider, particularly farmers and landowners. WRT has fulfilled this role in terms of payments from the UK Government, the EU, and South West Water.

This institutional model is now proving an inspiration for transfer (Benson and Jordan 2011) within the UK. As the first and, to date, arguably the most effective affiliated body of the national Association of Rivers Trusts (now renamed The Rivers Trust), the WRT is providing valuable lessons for other partnerships. This success has also been recognized by central government. Trust evidence submitted to the House of Lords Committee enquiry into EU water policy was reported back to the UK Government (House of Lords 2012). Their Lordships stated the following:

\begin{abstract}
The WRT works in partnership with external individuals and organisations to share expertise and facilitate better information transfer. By collaborating with a whole range of stakeholders - ranging from individual businesses through to academic institutions, NGOs and government departments - the Trust aims to circumvent sectoral interests and encourages joint solutions to the complex environmental problems our society currently faces. (House of Lords 2012:32)
\end{abstract}

\section{The politics of organizational design}

Organizational design and form cannot be separated from the overtly political nature of environmental management. Here, institutional interplay can be crucial to effectiveness, whereby RBOs must engage in wider political structures by managing relationships across scales to produce effective and adaptive comanagement governance that should benefit all (Huitema and Meijerink 2014). For example, in New Zealand, a tendency for one stakeholder group (such as farmers) to dominate policy and management processes has been noted (Mcneil 2013) and appropriate collective action must prevent such an occurrence. In UK water governance, government agencies are often in regulatory opposition with groups such as farmers. However, as a registered charity the WRT can operate as an honest broker to mediate between these stakeholders and cultivate trust between them. Through learning to incorporate these often competing values in collaborative decision making, the scope for conflict has consequently been reduced through organizational design.

These values reflect the underlying philosophy of the Trust's founders. Arlin Rickard, first director of the WRT and now Chief Executive of The Rivers Trust, suggests that a willingness to engage with stakeholders is critical to WRT effectiveness, in addition to securing funding to support projects (A. Rickard, personal communication, 2012). Without engagement, particularly with state agencies and the public, political relationships and operational frameworks can be compromised.
Critical mechanisms for incorporating these values into Trust operations have been techniques such as farm visits and stakeholder workshops. Farmer engagement, as discussed above, is particularly important. To date, over one thousand farmers have been supplied with individually tailored advice and/or support (WRT and Rickard 2013). Expert facilitators are also employed to bring stakeholders together and reconcile their views in workshops and in that way not only "opinion" farmers, within the farming community, but also other key stakeholders (water companies, regulatory bodies, and local authorities) have been involved (A. Rickard, personal communication, 2013).

\section{Functional performance}

Several criteria could be employed in assessing the performance of this organization (Huitema and Meijerink 2014). These functional criteria include the organizational capacity for coordination between competing policy objectives, plus accountability, democratic legitimacy, and environmental effectiveness. Using these indicators, an analysis of the WRT shows that it has developed into a relatively effective example of, first, a partnership organization and, second, an RBO. However, to be more successful, the functions of the WRT require better integration with the higher level regional scale river basin district and the activities of government agencies.

Coordination is related to $\mathrm{RBO}$ capacities to reconcile decisions horizontally between policy sectors and vertically across levels of government (Huitema and Meijerink 2014). In this respect, the WRT approach to horizontally coordinating decision making allows some inclusivity, adaptability, and flexibility to overcome challenges from contradictory politics and spatial fit. The status of the WRT as an ethical broker, combined with its spatial functions, means that it can perform this horizontal intersector coordination. This status is particularly important in reconciling the often competing interests of intensive farming, driven by political and commercial imperatives, with the environment and users of environmental services. One significant mechanism for coordination is PES. For example, the Upstream Thinking model coordinates the actions of agricultural producers of an environmental good, in this case clean drinking water, with the needs of end consumers, namely South West Water and their customers. In addition, to coordinating between divergent (and often competing) commercial sectors, the Trust could also provide a vertical linking role with regional governance scales. Authority rules within the agency-type river basin districts focus on achieving good ecological status objectives for waters, often placing the EA in direct conflict with farmers and industry. As demonstrated by the WRT projects, catchment scale initiatives could provide a strong supporting input to achieving higher level objectives. One concern therefore, in terms of coordination, is how vertical coordination is being achieved in practice, not only by the Trust but through other emergent catchment partnerships. According to Trust managers, this is particularly poignant in relation to a perceived lack of clarity regarding how catchment partnerships link with the river basin liaison panels and then to the National Liaison Panel.

Potential criticisms of partnership RBOs could revolve around whether they can, ironically, lead to reduced public accountability through domination by sectoral interests, for example, environmentalists or land owners. Initially, the Trust comprised a select group of local actors but, in response, its public 
accountability has been gradually expanded. A good example of how inclusivity extends accountability is through multiactor projects such as the TCP. As a registered charity, the WRT must also conform to legal criteria that set out strict governance standards that are enforced by government. Conditions are additionally imposed on project activities by various funding bodies such as the European Union. Consequently, the Trust is accountable to its membership, funders, the wider public, and public authorities. However, it could be argued that accountability can be enhanced through greater public representation in the Trust's governance through, for example, local government interaction. This observation reflects a wider concern over the accountability of catchment groups in England and Wales, where charities and private interests are influential (Cook et al. 2012). In contrast, Environment Agency actors are indirectly democratically accountable to the public through higher level political control, a factor not evident with catchment partnerships.

Some success is also evident if we consider legitimacy. It is hypothesized that partnerships may generate greater input legitimacy than agency RBOs but that in contrast, because of the complexity of multiactor decision making, they may provide lower output legitimacy (Huitema and Meijerink 2014). Depending on how output legitimacy is measured, however, the Trust would mainly disprove this proposition. Input legitimacy is potentially strong because of the relatively inclusive nature of decision making, although representativeness could be questioned where the democratic controls associated with government agencies and local government are absent. More saliently, outputs of goods and services are measurably high. Indicators of output success such as advice provided for land managers, plans produced, best management practices adopted, landscape restoration achieved, farm efficiency savings made, and funds channelled to local actors through the various projects and innovative PES schemes, all show a positive trend over time. These findings could potentially inform learning on legitimacy for RBO institutional design elsewhere, particularly regarding the observed need for partnerships to prioritize actor inclusivity and also attain quantifiable outputs. The latter appears particularly important in maintaining WRT legitimacy with key farming stakeholders. Yet, greater comparative research into the factors shaping partnership output legitimacy is required beyond this single case.

Environmental effectiveness can be measured via the attainment of environmental goals. Immediate improvements in water quality are often difficult to demonstrate with adaptive forms of catchment management because of the long run nature of planning cycles (Sabatier et al. 2005). Evidence from internal WRT pilot studies points to localized improvements in water quality. Proxy indicators of environmental effectiveness (see Benson et al. 2014) such as the farm best management practice plans, habitat restoration projects, stakeholder engagement, and PES schemes all support future improvements in catchment environmental quality. What is less certain is how these improvements are contributing to meeting wider WFD objectives, suggesting a need to better coordinate planning measures and monitoring of goal attainment.

\section{CONCLUSIONS}

The WRT could provide some positive lessons for bioregional approaches, if considered a normative goal, in its institutional design and effectiveness. Drawing upon Ostrom (1986), authority rules have also created a largely nonhierarchical, institutionally self-organizing governance form with task-specific competences, i.e., managing environmental quality. As a charity, the Trust is also able to mobilize resources, support, and legitimacy in ways not readily available to agency-centered RBOs. Aggregation rules are based on collaboration and consensus between multiple stakeholders, avoiding domination by one group. Indeed, the WRT is pioneering such processes both nationally and within Europe. Boundary rules dictate local bioregionalism combined with multiactor engagement. Projects have focused on environmental improvements in specific catchments, involving farmers, industry, government agencies, and the public. Information rules determine utilizing local knowledge alongside technical-scientific information. Critically, the WRT demonstrates that pay-off rules should promote seeking out win-win outcomes, in its case by playing the role of an honest broker, rather than creating winners and losers. The Payments for Ecosystems Services schemes provide a good example of the practical application of this philosophy. In addition, returning to Pepper's (1996) bioregionalism principles, the Trust has facilitated local empowerment through its communitarian approach.

However, as discussed above, the implementation of bioregionalism can be problematic. Although the Trust illustrates how bioregional approaches could support economically and ecologically positive action at a local scale, questions remain over democratic accountability and the inclusiveness of decision making. Further research is therefore required into how the Trust and other similar organizations address these concerns, as a basis for comparative lesson-drawing. How legitimacy is established and maintained is another area of interest, particularly the extent to which it is linked to the production of specific outputs. There is also an observed need in England and Wales to investigate how local partnership activity can be better connected with higher level governance processes implementing the WFD. The Trust, in this sense, can potentially complement agency-led approaches to improving water quality through river basin management planning. However, there is evident potential for interinstitutional coordination problems to develop as Trust boundaries do not coincide with regional scale WFD processes. This feature highlights a more general challenge for proponents of bioregionalism, namely how to move from normatively promoting localism as an ideal, to demonstrating how it can effectively integrate within multiple levels of governance, which are an increasingly important characteristic of water management globally. Overcoming scale mismatches between partnership type RBOs based on bioregionally defined areas and actual political boundaries remains critical to meeting this challenge.

\footnotetext{
${ }^{[1]}$ The UK government has also promoted Catchment Sensitive Farming, which aims at encouraging farm best management practice through financial and technical assistance, although these schemes cannot be considered genuine RBOs.
}

Responses to this article can be read online at: http://www.ecologyandsociety.org/issues/responses. $\mathrm{php} / 8504$ 


\section{Acknowledgments:}

We thank Arlin Rickard (The Rivers Trust), Dr Dylan Bright (WRT), and Martin Ross of South West Water plc for their advice and information. Writing of this article was supported by the Leverhulme Trust (International Network scheme). The text is adapted from the book chapter in The Politics of River Basin Organisations: Coalitions, Institutional Design Choices and Consequences (Huitema and Meijerink 2014). We thank Edward Elgar Publishing who have kindly given permission for the use of material from D. Huitema and S. Meijerink, editors. 2014. The Politics of River Basin Organisations. Coalitions, Institutional Design Choices and Consequences. Edward Elgar Publishing, Cheltenham, UK.

\section{LITERATURE CITED}

Aberley, D. 1999. Interpreting bioregionalism. Pages 13-42 in M. V. McGinnis, editor. Bioregionalism. Routledge, New York, New York, USA.

Bell, S., and D. McGillivray. 2000. Environmental law. Fifth edition. Blackstone Press, London, UK.

Benson, D., O. Fritsch, H. Cook, and M. Schmid. 2014. Evaluating participation in WFD river basin management in England and Wales: processes, communities, outputs and outcomes. Land Use Policy 38:213-222. http://dx.doi.org/10.1016/ j.landusepol.2013.11.004

Benson, D., and A. Jordan. 2011. What have we learnt from policy transfer research? Dolowitz and Marsh revisited. Political Studies Review 9(3):366-378. http://dx.doi.org/10.1111/j.1478-9302.2011.00240. $\underline{x}$

Benson, D., A. Jordan, and L. Smith. 2013. Is environmental management really more collaborative? A comparative analysis of putative 'paradigm shifts' in Europe, Australia, and the United Sates. Environment and Planning A 45(7):1695-1712. http://dx.doi. org/10.1068/a45378

Cook, B. R., M. Atkinson, H. Chalmers, L. Comins, S. Cooksley, N. Deans, I. Fazey, A. Fenemor, M. Kesby, S. Litke, D. Marshall, and C. Spray. 2013. Interrogating participatory catchment organisations: cases from Canada, New Zealand, Scotland and the Scottish-English Borderlands. Geographical Journal 179 (3):234-247. http://dx.doi.org/10.1111/j.1475-4959.2012.00492.x

Cook, H. F. 2016. The protection and conservation of water resources: a new British perspective. Wiley International, London, UK.

Cook H., D. Benson, and A. Inman. 2014. Partnering for success in England: the Westcountry Rivers Trust. Pages 119-139 in D. Huitema and S. Meijerink, editors. The politics of river basin organisations: coalitions, institutional design choices and consequences. Edward Elgar, Cheltenham, UK. http://dx.doi. org/10.4337/9781782549222.00010

Cook, H., D. Benson, A. Inman, A. Jordan, and L. Smith. 2012. Catchment management groups in England and Wales: extent, roles and influence. Water and Environment Journal 26(1):47-55. http://dx.doi.org/10.1111/j.1747-6593.2011.00262.x
Cook, H., and A. Inman. 2012. The voluntary sector and conservation for England: achievements, expanding roles and uncertain future. Journal of Environmental Management 112:170-177. http://dx.doi.org/10.1016/j.jenvman.2012.07.013

Cornwall Rivers Project. 2008. Cornwall Rivers Project. Westcountry Rivers Trust, Callington, Cornwall, UK. [online] URL: http://www.cornwallriversproject.org.uk/

Day, B., and L. Couldrick. 2013. Payment for ecosystem services pilot project: the Fowey River Improvement Auction. Final report. The University of East Anglia, Norwich, UK and Westcountry Rivers Trust, Callington, Cornwall, UK. [online] URL: http:// randd.defra.gov.uk/Document.aspx? Document=11542 FoweyAuctionFinalReportNe0131.pdf

Department for Environment, Food \& Rural Affairs (Defra). 2006. Case studies aimed at reducing diffuse water pollution from agriculture in England. Defra, London, UK.

Department for Environment, Food \& Rural Affairs (Defra). 2013. Catchment based approach: improving the quality of our water environment. Defra, London, UK.

Dunn, H. 2011. Payments for ecosystem services. Defra Evidence and Analysis Service, Paper 4. Defra, London, UK.

Environment Agency (EA). 2009. Water for life and livelihoods: river basin management plan - South West River Basin District. Environment Agency, Bristol, UK.

Environment Agency (EA). 2014. Draft update to the river basin management plan for the South West River Basin District. Environmental Report. Environment Agency, Bristol, UK. [online] URL: https://consult.environment-agency.gov.uk/portal/ ho/wfd/draft plans/consult?pointId=s1405418011983

European Communities. 2000. Directive 2000/60/EC of the European Parliament and of the Council of 23 October 2000 Establishing a Framework for Community Action in the Field of Water Policy. Official Journal of the European Communities, L $327 / 1$ of 22.12.2000. EC, Brussels, Belgium.

Fritsch, O., and D. Benson. 2013. Integrating the principles of integrated water resources management? River basin planning in England and Wales. International Journal of Water Governance 1 (3/4):265-283. http://dx.doi.org/10.7564/13-IJWG7

Gray, R. 2007. Practical bioregionalism: a philosophy for a sustainable future and a hypothetical transition strategy for Armidale, New South Wales, Australia. Futures 39(7):790-806. http://dx.doi.org/10.1016/j.futures.2006.12.003

Haigh, N. 2005. Manual of environmental policy: the EU and Britain. Maney Publishing and Institute for European Environmental Policy, London, UK.

House of Lords. 2012. European Union Committee - Thirty-Third Report. An Indispensable Resource: EU Freshwater Policy. House of Lords, London, UK. [online] URL: http://www.publications. parliament.uk/pa/ld201012/ldselect/ldeucom/296/29602.htm

Huitema, D., and S. Meijerink, editors. 2014. The politics of river basin organisations: coalitions, institutional design choices and consequences. Edward Elgar, Cheltenham, UK. http://dx.doi. org/10.4337/9781782549222.00006 
Ker Rault, P. A., and P. J. Jeffrey. 2008. Deconstructing public participation in the Water Framework Directive: implementation and compliance with the letter or with the spirit of the law? Water and Environment Journal 22(4):241-249. http://dx.doi.org/10.1111/ j.1747-6593.2008.00125.x

Kropotkin, P. A. 1974. Fields, factories and workshops. George Allen and Unwin, London, UK.

Leach, W. D., and N. W. Pelkey. 2001. Making watershed partnerships work: a review of the empirical literature. Journal of Water Resources Planning and Management 127(6):378-385. http://dx.doi.org/10.1061/(asce)0733-9496(2001)127:6(378)

Margerum, R. D. 2011. Beyond consensus: improving collaborative planning and management. MIT Press, Cambridge, Massachusetts, USA. http://dx.doi.org/10.7551/mitpress/9780262015813.001.0001

McGinnis, M. V., editor 1999. Bioregionalism. Routledge, New York, New York, USA.

Mcneil J. 2013. The legitimacy of IWRM scale politics: lessons from New Zealand. European Consortium for Political Research General Conference. ECPR, Colchester, UK. [online] URL: http:// www.ecpr.eu/Events/PaperDetails.aspx?PaperID=3234\&EventID=5

Office for National Statistics (ONS). 2012. The geography of tourism employment. ONS, Cardiff, UK. [online] URL: http:// www.ons.gov.uk/ons/dep171776_287932.pdf

Ostrom, E. 1986. An agenda for the study of institutions. Public Choice 48(1):3-25. http://dx.doi.org/10.1007/bf00239556

Pepper, D. 1996. Modern environmentalism: an introduction. Routledge, London, UK. http://dx.doi.org/10.4324/9780203412244

Plummer, R. 2009. The adaptive co-management process: an initial synthesis of representative models and influential variables. Ecology and Society 14(2):24. [online] URL: http://www. ecologyandsociety.org/vol14/iss2/art24/

Sabatier, P. A., W. Focht, M. Lubell, Z. Trachtenberg, A. Vedlitz, and M. Matlock. 2005. Swimming upstream: collaborative approaches to watershed management. MIT Press, Cambridge, Massachusetts, USA.

Sale, K. 1985. Dwellers in the land: the bioregional vision. Sierra Club Books, San Francisco, California, USA.

Smith, L. E. D., and K. S. Porter. 2009. Management of catchments for the protection of water resources: drawing on the New York City watershed experience. Regional Environmental Change 10(4):311-326. http://dx.doi.org/10.1007/s10113-009-0102-

$\underline{z}$

South West Water. [date unknown]. Managing catchments: upstream thinking. South West Water, Exeter, UK. [online] URL: http://www.southwestwater.co.uk/index.cfm?articleid=11682

URS/Scott Wilson. 2011. Barriers and opportunities to the use of payments for ecosystem services. Final Report. URS/Scott Wilson, London, UK.

Westcountry Rivers Trust (WRT). 2012. Westcountry Rivers Trust. Westcountry Rivers Trust, Stoke Climsland, Callington, UK. http://www.wrt.org.uk/
Westcountry Rivers Trust (WRT). [date unknown]. Intelligent catchment design? Westcountry Rivers Trust, Stoke Climsland, Callington, UK.

Westcountry Rivers Trust (WRT), and A. Rickard. 2013. The ecosystem approach and rivers trusts: the Westcountry Rivers Trust. Westcountry Rivers Trust, Stoke Climsland, Callington, UK. [online] URL: http://www.theriverstrust.org/environment/ecosystem/ eco approach.htm 